\title{
Dietary choline enhanced skin immune response of juvenile grass carp might be related to STAT3 and NF-kB signaling pathway (Ctenopharyngodon idella)
}

\section{Ze-Hong Yuan}

Sichuan Agricultural University

Lin Feng

Sichuan Agricultural University

Wei-dan Jiang

Sichuan Agricultural University

\section{Pei Wu}

Sichuan Agricultural University

\section{Yang Liu}

Sichuan Agricultural University

Jun Jiang

Sichuan Agricultural University

\section{Sheng-yao Kuang}

Sichuan Animal Sciences Academy

\section{Ling Tang}

Sichuan Animal Sciences Academy

Xiao-Qiu Zhou ( $\nabla$ fishnutrition@126.com )

Animal Nutrition Institute

\section{Research}

Keywords: Juvenile grass carp (Ctenopharyngodon idella), Immune function, Choline, Skin, JAK/STAT3, NF-KB signaling

Posted Date: December 2nd, 2020

DOl: https://doi.org/10.21203/rs.3.rs-118695/v1

License: (c) (i) This work is licensed under a Creative Commons Attribution 4.0 International License. Read Full License 


\section{Abstract}

Background: Choline is an indispensable vitamin of fish; which deficiency affects fish health. Fish health is affected by skin immune function. Hence, the present study was conducted to investigate the effects of dietary choline on skin immune function as well as underlying mechanisms of juvenile grass carp (Ctenopharyngodon idella).

Results: The results exhibited that dietary choline (1) advanced the content of phosphatidylcholine (PC), betaine, and choline in grass crap skin $(P<0.05)$, up-regulated the mRNA abundance of choline transporter CHT1, CTL5, and CTL1 indicating that dietary choline could increase the contents of choline might be connected with choline transporters in the grass carp skin; (2) receded skin lesion and increased the level of $\lg M, C 4, C 3$, and the activities of acid phosphatase (ACP) and lysozyme activity (LZ), raised mucin2, $\beta$-defensin, hepcidin, and LEAP-2B mRNA abundance (rather than LEAP-2A), down-regulated pro-inflammatory cytokines mRNA abundance (IFN- $\gamma 2$, IL-15, TNF-a, IL-6, IL-12P40, and IL-1 $\beta$ ) in skin of juvenile grass carp $(P<0.05)$, up-regulated anti-inflammatory cytokines mRNA abundance ( IL-10, IL-4/13A, TGF- $\beta 1$, IL-11, and IL-4/13B) in grass crap skin $(P<0.05)$ demonstrating that choline enhanced the skin immune function; (3) down-regulated the mRNA abundance of IKKy, NF-kBp52, , IKKß, c-Rel, NF-kBp65, STAT3b2, STAT3b1 JAK1, and JAK2 as well as protein level of NF-KBp65 and p-STAT3 Tyr705 in nucleus, inhibited the mRNA and protein level of IkBa $(P<0.05)$, indicating that choline enhanced immune function might be relevant to JAK/STAT3 and NF-KB signaling pathway in fish skin.

Conclusions: In conclusion, choline enhanced the skin immune function might be relate to JAK/STAT3 and NF-KB signaling molecules in fish. Furthermore, based on immune indices of grass carp (9.28-108.97g) skin (C3 and lgM contents as well as ACP activities), the choline requirements were estimated to be 1475.81, 1364.24, and 1574.37 $\mathrm{mg} / \mathrm{kg}$ diet, respectively.

\section{Introduction}

Intensive aquaculture increases diseases infection risk of fish[1]. Improving immunity is crucial for the prevention and control of diseases in fish[2]. Skin is a crucial immune organ in fish[3], whose health is important for fish growth and diseases resistance[4]. Fish skin immune function is tightly correlated with specific immune factors like immunoglobulins and nonspecific immune factors like LZ [5]. Furthermore, fish skin immunity is closely related to the cytokines. Murray (2008) found that anti-inflammatory cytokines could be regulated by STAT3 as well as upstream signaling molecule Janus kinases (JAK) in humans [6], while pro-inflammatory cytokines expression could be mediated by NF-KB[7]. Vitamin B like biotin (VB7) could enhance the immune function of grass carp skin[8]. However, as a vitamin $B$, no researches regarding the effect of choline on fish skin immunologic function and potential mechanisms. Choline enters the cell via choline transporters and produce corresponding metabolite to play biological functions[9]. Betaine as one of vital metabolite, which could decrease the content of tumor necrosis factor-a (TNF-a) in rat liver[10, 11]. In mouse brain, choline enhanced the acetylcholine (ACh) level which could activate JAK2/STAT3 signaling pathway in mouse PC12 cells[12, 13]. In human, choline synthesis PC which restrained NF-KBp65 protein level in rat IEC-6 cells[14, 15]. Thus, there might be a relationship between immune function and choline, which may be related to JAK/STAT3 and NF-KB signaling pathway in fish skin. This research is of great value.

Most researches of vitamins concentrated on liver health and nutritional requirements [16, 17]. So far, scattered reports regarding the impacts of vitamin on fish skin immunity. And there still remain following restrictions: 1) in limited researches, we found that those researches are not deeply and systematically enough. Most studies mainly focused on the antibiotic substance contents and the inflammatory factors gene expression, did not investigate the involved mechanisms $[8,18]$. 2) the in-depth mechanisms of various vitamin on fish skin immune function are contrasting. Such as, dietary VB7 supplement enhanced skin immune function might be connected with key enzymes activity such as 
acid phosphatase (ACP)[8], whereas VC did not change the activity of ACP in fish skin [18]. Hence, it's necessary to systematically research the impacts of choline on fish skin immunity.

In current study, the growth trial was selfsame to our prior study. The study determines the dietary choline enhanced fish growth performances [19] which were influenced by the skin immune function[20]. Grass carp are the world's most farmed fish [21]. Hence, we explored the influences of choline on fish skin immune function, which partially declared the impact of choline on skin immune function and underlying mechanisms in fish. Simultaneously, vitamin requirements based on fish production performance are lower than the immune function of juvenile grass carp [18, 22], so we determined the optimum choline requirements depend on the immune indicator for juvenile grass carp, which may provide basis for production practice.

\section{Material And Methods}

\subsection{Experiments and feeding management}

The current study used the selfsame animal trial as our prior research [19]. The feed formula showed in Table 1, which was commensurate with prior research. Fishes were fed with 6 various gradient choline dietary for 70 days. The choline levels were 142.2 (0), 407.4 (400), 821.6 (800), 1215.8 (1200), 1589.3 (1600) and 1996.6 (2000) $\mathrm{mg} \mathrm{kg}^{-1}$ in 6 diets, respectively (The value in front of the brackets is the measured value, and the value in the brackets is the design value). The actual choline level was determined by the way from Ding and Mou [23], 
Table 1

Composition and nutrients of basal diet.

\begin{tabular}{|c|c|c|c|}
\hline Ingredients & $\%$ & nutrients & $\%$ \\
\hline Fish meal & 3.97 & Crude protein $^{d}$ & 31.92 \\
\hline Casein & 28.27 & Crude lipid $^{d}$ & 4.22 \\
\hline Gelatin & 7.00 & n-3 Fatty & 1.04 \\
\hline a-starch & 24.00 & n-6 Fatty & 0.96 \\
\hline Corn starch & 18.72 & Available phosphorus & 0.84 \\
\hline Fish oil & 2.63 & & \\
\hline Soybean oil & 1.80 & & \\
\hline Microcrystalline cellulose & 5.00 & & \\
\hline $\mathrm{Ca}\left(\mathrm{H}_{2} \mathrm{PO}_{4}\right)_{2}$ & 3.30 & & \\
\hline Choline-free vitamin premix ${ }^{a}$ & 1.00 & & \\
\hline Mineral premix ${ }^{b}$ & 2.00 & & \\
\hline Choline chloride premix ${ }^{c}$ & 2.00 & & \\
\hline DL-Met(99\%) & 0.26 & & \\
\hline Ethoxyquin (30\%) & 0.05 & & \\
\hline \multicolumn{4}{|c|}{ 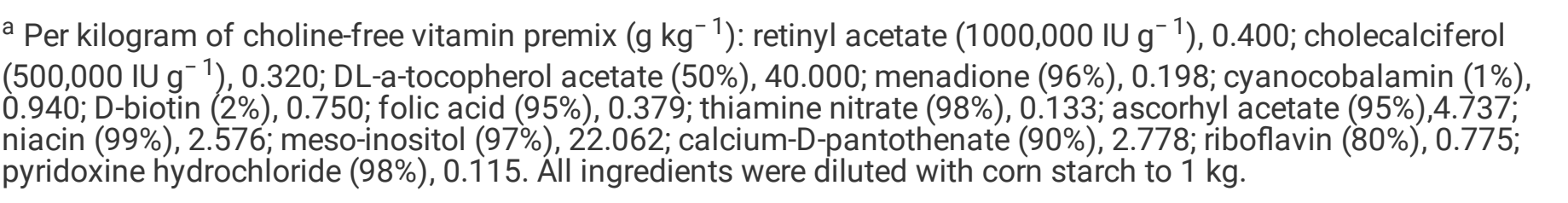 } \\
\hline \multicolumn{4}{|c|}{$\begin{array}{l}{ }^{b} \text { Per kilogram of mineral premix }\left(\mathrm{g} \mathrm{kg}^{-1}\right): \mathrm{MnSO}_{4} \cdot \mathrm{H}_{2} \mathrm{O}(31.8 \% \mathrm{Mn}), 3.098 ; \mathrm{MgSO}_{4} \cdot \mathrm{H}_{2} \mathrm{O}(15.0 \% \mathrm{Mg}), 237.840 ; \\
\mathrm{FeSO}_{4} \cdot \mathrm{H}_{2} \mathrm{O}(30.0 \% \mathrm{Fe}), 15.000 ; \mathrm{ZnSO}_{4} \cdot \mathrm{H}_{2} \mathrm{O}(34.5 \% \mathrm{Zn}), 7.860 ; \mathrm{CuSO}_{4} \cdot 5 \mathrm{H}_{2} \mathrm{O}(25.0 \% \mathrm{Cu}), 0.600 ; \mathrm{Cal}_{2}(3.2 \% \mathrm{I}), 1.560 ; \\
\mathrm{Na}_{2} \mathrm{SeO}_{3}(44.7 \% \mathrm{Se}), 0.132 \text {. All ingredients were diluted with corn starch to } 1 \mathrm{~kg} \text {. }\end{array}$} \\
\hline \multicolumn{4}{|c|}{$\begin{array}{l}\text { c Per kilogram of choline chloride premix ( } \mathrm{g} / \mathrm{kg} \text { ): premix was added to obtain graded level of choline. Each choline } \\
\text { chloride mixture was diluted with corn starch to } 1 \mathrm{~kg} \text { referenced to Wu et al. (2010) }\end{array}$} \\
\hline \multicolumn{4}{|c|}{ d Crude protein and crude lipid contents were measured values. } \\
\hline \multicolumn{4}{|c|}{ e n-3 and n-6 were calculated by NRC (2011) contents were referenced to Zeng et al. (2016). } \\
\hline${ }^{f}$ Available phosphorus were c & o NRC & & \\
\hline
\end{tabular}

All experimental procedures were approved by Animal Protection Advisory Committee of Sichuan Agricultural University [24]. Fishes were purchased from the fishery (Chengdu, China). Before the experiment, 4-weeks feeding was to adapt to the environment. After that 1440 fishes with average weight of $9.29 \mathrm{~g}$ were randomly assigned to 36 aquariums $\left(0.144 \mathrm{~m}^{3}\right)$. The same continuous aeration and recirculating water was maintained to each aquarium [25]. During 
growth experiment, the dissolved oxygen level ranged from $6.2 \mathrm{mg} / \mathrm{L}$ to $7.0 \mathrm{mg} / \mathrm{L}, \mathrm{pH}$ was measured at $7.0 \pm 0.3$ and water temperature at $28 \pm 2{ }^{\circ} \mathrm{C}$. Fishes were fed 4 times every day[24, 26].

\subsection{Challenge test}

The bacteria were supplied by college of Veterinary Medicine, Sichuan Agricultural University. Prior to initiation of the challenge test, based on skin lesion morbidity, we determined appropriate challenge concentration after injection graded levels of $A$. hydrophila in fish. After 70 days of feeding, 42 fishes with similar body weight were intraperitoneal challenge injection with $2.1 \times 10^{6} \mathrm{CFU} / \mathrm{ml}$ A. hydrophila. After injection for 6 days[27], put the skin of each group into liquid nitrogen, and reserved in $-80^{\circ} \mathrm{C}$.

\subsection{Measurement of choline metabolite contents and immune parameters activities}

$10 \%$ fish tissue homogenate was prepared to detected the caspase activities and choline metabolite level as described [1]. Using commercial assay kits (Nanjing Jiancheng Bioengineering Institute) to detected the IgM, C4, C3 ACP and LZ levels according to Takemura et al. (1993), Huang et al. [28, 29]. The level of ACh, betaine, PC, and choline were determined by ELISA kits (Shanghai Kexing Trading Co., Ltd, China). The level of ACh, betaine, PC, and choline were calculated on the basis of standard curves.

\subsection{Quantitative real-time PCR}

The skin total RNA was extract using RNAiso Plus kit (TaKaRa Bio Inc., Japan) following the specification. Thenceforth, referring the instruction to synthase cDNA by PrimeScript ${ }^{T M}$ RT reagent Kit (TaKaRa). The qRT-PCR primers were referred to the published sequences of grass carp in our lab prior study, which were shown in Table 2. The gene amplification

efficiency was measured by melting curve. Using $2^{-\triangle \Delta C T}$ method to calculate the gene expression as described by Hu et al [30]. 
Table 2

Real-time PCR primer sequences.

\begin{tabular}{|c|c|c|c|c|}
\hline $\begin{array}{l}\text { Target } \\
\text { gene }\end{array}$ & $\begin{array}{l}\text { Primer sequence Forward } \\
\left(5^{\prime} \rightarrow 3^{\prime}\right)\end{array}$ & Primer sequence Reverse $\left(5^{\prime} \rightarrow 3^{\prime}\right)$ & $\begin{array}{l}\text { Temperature } \\
\left({ }^{\circ} \mathrm{C}\right)\end{array}$ & $\begin{array}{l}\text { Accession } \\
\text { number }\end{array}$ \\
\hline IL-6 & CAGCAGAATGGGGGAGTTATC & CTCGCAGAGTCTTGACATCCTT & 62.3 & KC535507.1 \\
\hline IL-12p35 & TGGAAAAGGAGGGGAAGATG & AGACGGACGCTGTGTGAGTGTA & 55.4 & KF944667.1 \\
\hline IL-12p40 & ACAAAGATGAAAAACTGGAGGC & GTGTGTGGTTTAGGTAGGAGCC & 59 & KF944668.1 \\
\hline IL-15 & ССТTССААСААТСТСGСТTC & ААСАСАТСТTССАGТTСТССТT & 61.4 & KT445872.1 \\
\hline IL-17D & GTGTCCAGGAGAGCACCAAG & GCGAGAGGCTGAGGAAGTT T & 62.3 & KF245426.1 \\
\hline IL-4/13A & CTACTGCTCGCTTTCGCTGT & CCCAGTTTTCAGTTCTCTCAGG & 55.9 & KT445871.1 \\
\hline IL-4/13B & TGTGAACCAGACCCTACATAACC & TTCAGGACCTTTGCTGCTTG & 55.9 & KT625600.1 \\
\hline TNF-a & CGCTGCTGTCTGCTTCAC & CCTGGTCCTGGTTCACTC & 58.4 & HQ696609 \\
\hline IFN-ץ2 & TGTTTGATGACTTTGGGATG & TCAGGACCCGCAGGAAGAC & 60.4 & JX657682 \\
\hline IL-1 $\beta$ & AGAGTTTGGTGAAGAAGAGG & TTATTGTGGTTACGCTGGA & 57.1 & JQ692172 \\
\hline TGF- $\beta 1$ & TTGGGACTTGTGCTCTAT & AGTTCTGCTGGGATGTTT & 55.9 & EU099588 \\
\hline TGF- $\beta 2$ & TACATTGACAGCAAGGTGGTG & TCTTGTTGGGGATGATGTAGTT & 55.9 & KM279716 \\
\hline IL-10 & AATCCCTTTGATTTTGCC & GTGCCTTATCCTACAGTATGTG & 61.4 & HQ388294 \\
\hline IL-11 & GGTTCAAGTCTCTTCCAGCGAT & TGCGTGTTATTTTGTTCAGCCA & 57 & KT445870.1 \\
\hline Hepcidin & AGCAGGAGCAGGATGAGC & GCCAGGGGATTTGTTTGT & 59.3 & JQ246442.1 \\
\hline LEAP-2A & TGCCTACTGCCAGAACCA & AATCGGTTGGCTGTAGGA & 59.3 & FJ390414 \\
\hline LEAP-2B & TGTGCCATTAGCGACTTCTGAG & ATGATTCGCCACAAAGGGG & 59.3 & KT625603.1 \\
\hline $\begin{array}{l}\text { Bdefensin- } \\
1\end{array}$ & TTGCTTGTCCTTGCCGTCT & AATCCTTTGCCACAGCCTAA & 58.4 & KT445868.1 \\
\hline Mucin2 & GAGTTCCCAACCCAACACAT & AAAGGTCTACACAATCTGCCC & 60.4 & KT625602 \\
\hline CTL1 & GAACCGCAGGAAGTCCAGTG & GCTGACAGGCGAGGATGAACT & 60.7 & MN904650 \\
\hline CTL2 & AACTTCGTGACAGCATTGGG & ATGGCAAGAATGAGGGAACC & 58.6 & MN904651 \\
\hline CTL4 & GGTCATTGCGATGGTGGTC & CAGATACCGAAGGCTCCGAC & 59.2 & MN904652 \\
\hline CTL5 & GCAAAGGAAATCGGCATC & GCGGTGAACCTCAGCAGC & 57.8 & MN904653 \\
\hline CHT1 & TССТСАТСАСССАСАCGA & CCGАСТССТССАТССТСТС & 55.4 & MN904654 \\
\hline NF-кB p52 & TCAGTGTAACGACAACGGGAT & ATACTTCAGCCACACCTCTCTTAG & 58.4 & KM79720 \\
\hline NF-kB p65 & GAAGAAGGATGTGGGAGATG & TGTTGTCGTAGATGGGCTGAG & 62.3 & KJ526214 \\
\hline c-Rel & GCGTCTATGCTTCCAGATTTACC & АCTGCCACTGTTCTTGTTCACC & 59.3 & KT445865 \\
\hline IKBa & TCTTGCCATTATTCACGAGG & TGTTACCACAGTCATCCACCA & 62.3 & KJ125069 \\
\hline IKKa & GGCTACGCCAAAGACCTG & CGGACCTCGCCATTCATA & 60.3 & KM279718 \\
\hline $\mathrm{IKK} \beta$ & GTGGCGGTGGATTATTGG & GCACGGGTTGCCAGTTTG & 60.3 & KP125491 \\
\hline
\end{tabular}




\begin{tabular}{|lllll|}
\hline $\begin{array}{l}\text { Target } \\
\text { gene }\end{array}$ & $\begin{array}{l}\text { Primer sequence Forward } \\
\left(\mathbf{5}^{\prime} \rightarrow \mathbf{3}^{\prime}\right)\end{array}$ & Primer sequence Reverse $\left(\mathbf{5}^{\prime} \rightarrow \mathbf{3}^{\prime}\right)$ & $\begin{array}{l}\text { Temperature } \\
\left({ }^{\circ} \mathrm{C}\right)\end{array}$ & $\begin{array}{l}\text { Accession } \\
\text { number }\end{array}$ \\
\hline IKKY & AGAGGCTCGTCATAGTGG & CTGTGATTGGCTTGCTTT & 58.4 & KM079079 \\
\hline JAK1 & TTTGCTGCACTGGTGGACA & GCGCAGGACATAGGTTCCTT & 60.0 & KT724352.1 \\
\hline JAK2 & AGAGGCCATCGAGAGCTACT & TCATACGCCCCAACTGCAA & 59.7 & JF825474.1 \\
\hline JAK3 & GCCGTTCAAGTGTCTGGAGA & AACTCAGCCTCCATGCACT & 59.5 & KU200686.1 \\
\hline TYK2 & TTCGCCGTGTGTTTGCAAA & ACGCCAAAATGAGGAGCCA & 59.7 & KT724353.1 \\
\hline STAT3a & ACATTCCTGCTGCGCTTCA & ACGAGGATGTTGGTGGCAT & 59.8 & KC978890 \\
\hline STAT3b1 & TCAACATGGCCCAGTGGAA & AGCGTTGCGTGAGATTCCT & 59.4 & KU559609 \\
\hline STAT3b2 & GCTGACCAACCATCCAAA & CGGAGTAGTTTACACACGGAC & 54.5 & KU559610 \\
\hline B-actin & GGCTGTGCTGTCCCTGTA & GGGCATAACCCTCGTAGAT & 61.4 & M25013 \\
\hline
\end{tabular}

\subsection{Western blotting}

Using lysis buffer and protease inhibitor cocktail to prepare skin homogenate[7]. The protein level was determined by BCA assay kit (Beyotime Biotechnology Inc.). $\beta$-action, laminB1,p-STAT3Tyr705, NF-KBp65, and IkBa antibodies are same to our early research $[27,31]$. LaminB1 and $\beta$-Actin were used as control proteins for nuclei and cells total protein, respectively. protein samples were separated by DS-PAGE and shift to PVDF membrane. Using 5\% BSA to blocked PVDF membrane. After incubation the antibodies, using electrochemiluminescence (ECL) Kit to exposure. Finally, using Image Lab 5.1 software analyse western bands.

\subsection{Statistical analysis}

Using Shapiro-Wilk and Levene's tests to test the homogeneity and normal distribution of variance by SAS 8.1 (SAS Institute), respectively. Using one-way variance (ANOVA) to analysis data[32]. The significant differences between every treatment means were contrasted by Duncan's multiple range tests (significant difference at the $5 \%$ level of significance, $P<0.05[33])$. The choline requirement and correlations were estimated by broken-line mode and Pearson's correlation, respectively [24].

\section{Results}

\subsection{The contents of choline and its metabolites and the gene expression of choline transporter}

As shown in Table 3, the level of PC, betaine, and choline were raised with dietary choline up to $1589.3,1589.3$, and $1215.8 \mathrm{mg} / \mathrm{kg}(P<0.05)$, and then plain, respectively. However, the content of ACh did not change with the increase of choline content $(P>0.05)$. Choline transporter mRNA abundance of skin were exhibited in Fig. 2, CTL2 and CTL5 mRNA abundance were raised with dietary choline add to 1215.8 , and $1589.3 \mathrm{mg} / \mathrm{kg}(P<0.05)$, respectively, then flat. HCT1 mRNA abundance was slowly increased with dietary choline addition $(P<0.05)$. Dietary choline did not change the mRNA abundance of CTL1 and CTL4 in fish skin $(P>0.05)$. 
Table 3

Effects of dietary choline (mg/kg diet) on choline, phosphatidylcholine (PC), betaine and acetylcholine (Ach) contents in the intestine of grass carp (Ctenopharyngodon idella). ${ }^{1}$

\begin{tabular}{|lllllll|}
\hline \multicolumn{7}{|c|}{ Dietary choline levels $(\mathrm{mg} / \mathrm{kg}$ diet $)$} \\
\hline$\mu \mathrm{g} / \mathrm{g}$ & 142.2 & 407.4 & 821.6 & 1215.8 & 1589.3 & 1996.6 \\
\hline choline & $165.73 \pm 5.79^{\mathrm{a}}$ & $169.51 \pm 6.50^{\mathrm{a}}$ & $\begin{array}{l}172.10 \pm \\
5.86^{\mathrm{ab}}\end{array}$ & $180.91 \pm 4.12^{\mathrm{c}}$ & $\begin{array}{l}178.62 \pm \\
5.75^{\mathrm{bc}}\end{array}$ & $\begin{array}{l}180.13 \pm \\
5.20^{\mathrm{c}}\end{array}$ \\
\hline betaine & $160.66 \pm$ & $184.97 \pm$ & $204.06 \pm 5.46^{\mathrm{c}}$ & $215.35 \pm$ & $230.80 \pm$ & $223.33 \pm$ \\
& $10.49^{\mathrm{a}}$ & $17.15^{\mathrm{b}}$ & & $10.03^{\mathrm{cd}}$ & $18.37^{\mathrm{d}}$ & $17.65^{\mathrm{d}}$ \\
\hline ACh & $81.67 \pm 4.69$ & $88.29 \pm 4.13$ & $88.45 \pm 8.61$ & $87.16 \pm 6.48$ & $86.68 \pm 5.77$ & $83.29 \pm 6.68$ \\
\hline PC & $1208.99 \pm$ & $1547.81 \pm$ & $1592.76 \pm$ & $1721.05 \pm$ & $1740.24 \pm$ & $1693.64 \pm$ \\
\hline & $151.88^{\mathrm{a}}$ & $136.72^{\mathrm{b}}$ & $77.37^{\mathrm{bc}}$ & $60.15^{\mathrm{cd}}$ & $92.68^{\mathrm{d}}$ & $95.1^{\mathrm{cd}}$ \\
\hline
\end{tabular}

\subsection{Skin rot morbidity and activities of immune parameters in grass carp skin.}

Choline insufficiency caused skin rot symptom, as shown in Fig. 1. As exhibited in Table 4, the activities of ACP and LZ in grass carp skin was ascend as dietary choline level increased to $1215.8 \mathrm{~g} / \mathrm{kg}(P<0.05)$, then plateaued. The level of $\mathrm{C} 3$, IgM, and C4 in the skin was ascend as dietary choline supplements to $1589.3,821.6$, and $1215.8 \mathrm{~g} / \mathrm{kg}(P<0.05)$, respectively, then all plateaued. The antibacterial peptides mRNA abundance of skin was presented in Table 3A, mucin2, and LEAP-2B mRNA abundance was raised with dietary choline level add to 1215.8 , and $821.6 \mathrm{mg} / \mathrm{kg}(P<$ $0.05)$, respectively, then flat. The mRNA levels of hepcidin, and $\beta$-defensin- 1 was raised with choline supplements to $1589.3 \mathrm{mg} / \mathrm{kg}(P<0.05)$, then decreased. Nevertheless, mRNA abundance of LEAP-2A did not influence by choline $(P>$ 0.05). As exhibition in Fig. 3B, the mRNA abundance of TNF-a, IL-15, IL-6, IL-12p40, and IL-1 $\beta$ in skin of juvenile grass carp were descend with dietary choline level increased to $821.6,1215.8,1589.3,1215.8$, and $1215.8 \mathrm{mg} / \mathrm{kg}$, respectively $(P<0.05)$, and then flat. The mRNA abundance of IFN- 2 in skin of juvenile grass carp were descend with dietary choline addition $(P<0.05)$. In Fig. 3C, the mRNA abundance of anti-inflammatory cytokine IL-4/13B, IL-10, IL-11, and IL4/13A in skin of fish $(P<0.05)$ were elevated with choline level increased to $1589.3,1215.8,1589.3$, and $1589.3 \mathrm{mg} / \mathrm{kg}$, respectively $(P<0.05)$. TGF- $\beta 1$ mRNA abundance in fish skin was elevated with dietary choline addition $(P<0.05)$. Remarkably, the mRNA abundance of IL-17D, TGF- $\beta 2$, IL-12p35 did not impact by dietary choline $(P>0.05)$. 
Table 4

Effects of dietary choline (mg/kg diet) on immune parameters in juvenile grass carp (Ctenopharyngodon idella) skin. ${ }^{1}$

\begin{tabular}{|c|c|c|c|c|c|c|}
\hline & \multicolumn{6}{|c|}{ Dietary choline levels (mg/kg diet) } \\
\hline & 142.2 & 407.4 & 821.6 & 1215.8 & 1589.3 & 1996.6 \\
\hline C3 & $11.08 \pm 1.00^{\mathrm{a}}$ & $15.25 \pm 1.29^{b}$ & $16.62 \pm 1.63^{b}$ & $19.24 \pm 0.91^{\mathrm{c}}$ & $20.97 \pm 1.06^{d}$ & $20.33 \pm 1.75^{\mathrm{cd}}$ \\
\hline $\mathrm{C} 4$ & $1.20 \pm 0.12^{\mathrm{a}}$ & $1.98 \pm 0.14^{b}$ & $3.07 \pm 0.24^{c}$ & $4.07 \pm 0.30^{d}$ & $3.51 \pm 0.32^{d}$ & $3.40 \pm 0.31^{d}$ \\
\hline $\lg M$ & $31.60 \pm 3.05^{a}$ & $30.53 \pm 2.97^{a}$ & $40.94 \pm 3.95^{b}$ & $42.02 \pm 2.53^{b}$ & $43.13 \pm 2.38^{b}$ & $41.79 \pm 4.18^{b}$ \\
\hline ACP & $66.83 \pm 7.15^{a}$ & $87.72 \pm 8.36^{b}$ & $88.47 \pm 7.70^{b}$ & $101.58 \pm 11.17^{c}$ & $117.07 \pm 7.53^{c}$ & $111.39 \pm 9.66^{c}$ \\
\hline LZ & $81.01 \pm 8.34^{\mathrm{a}}$ & $107.51 \pm 9.83^{b}$ & $114.73 \pm 10.49^{b}$ & $136.99 \pm 14.68^{\mathrm{c}}$ & $139.07 \pm 15.07^{c}$ & $128.97 \pm 6.95^{c}$ \\
\hline $\begin{array}{l}{ }^{1} \text { Valu } \\
\text { Lyso } \\
\text { com }\end{array}$ & $\begin{array}{l}\text { are means } \pm \mathrm{S} \\
\text { ne activity }(\mathrm{U} / \mathrm{r} \\
\text { ment } 4(\mathrm{mg} / \mathrm{g}\end{array}$ & $\begin{array}{l}(\mathrm{n}=6) \text {, and diff } \\
\text { protein); ACP, } \\
\text { tein); IgM, imm }\end{array}$ & $\begin{array}{l}\text { nt superscripts in } \\
\text { phosphatase (l } \\
\text { oglobulin M (mg }\end{array}$ & $\begin{array}{l}\text { he same row are } \\
\text { ngprotein); } C 3, \mathrm{co} \\
\text { protein). }\end{array}$ & $\begin{array}{l}\text { yificantly differe } \\
\text { plement } 3(\mathrm{mg} / \mathrm{g}\end{array}$ & $\begin{array}{l}(P<0.05) \\
\text { rotein); C4, }\end{array}$ \\
\hline
\end{tabular}

\subsection{JAK/STAT3 signaling pathways and NK-kB signaling pathways $m R N A$ abundance in fish skin}

As exhibition in Fig. 4, in juvenile grass carp skin, the mRNA abundance of IKK- $\gamma$, NF-kB p65, c-Rel, NF-kB p52, and IKK- $\beta$ were descend with dietary choline level to $1589.3,1215.8,1215.8,1589.3$, and $1589.3 \mathrm{mg} / \mathrm{kg}$, respectively $(P<0.05)$, and then plateaued. IKBa mRNA levels was increased with dietary choline level up to $1589.3(P<0.05)$, and then flat. In Fig. 5, the mRNA abundance of JAK1, JAK2, STAT3b1, and STAT3b2 were elevated with choline add to1215.8, 1589.3, 1589.3 , and $1589.3 \mathrm{mg} / \mathrm{kg}$, respectively $(P<0.05)$, and then plateaued. Tyk2 mRNA levels was highest in $407.4 \mathrm{mg} / \mathrm{kg}$ choline diet $(P<0.05)$. However, dietary choline had no influence on mRNA abundance of IKKa, JAK3, and STAT3a in skin of juvenile grass carp. As shown in Fig. 6, NF-kB p65 protein level in the nucleus was descend with choline supplements to $1215.8 \mathrm{mg} / \mathrm{kg}(P<0.05)$ then plateaued. The IKBa protein level and p-STAT3 Tyr705 protein level in the nucleus were elevated with dietary choline addition to $1589.5 \mathrm{mg} / \mathrm{kg}$, respectively $(P<0.05)$.

\section{Discussion}

This research used a growth experiment selfsame to our earlier study [19], which found choline improved fish growth performances of juvenile grass carp[19]. Furthermore, fish growth performances were deeply related to the immune function of immune organs[27], Hence, we explored how choline impact the skin immune function of fish in this study.

\subsection{Dietary choline increased the content of choline and its metabolites and up-regulated the gene expression of choline transporter in skin}

Dietary choline was absorbed by guts and through blood travels to different tissues where it can be oxidized, phosphorylated, acetylated and produce corresponding metabolite, such as betaine, PC, and ACh. In our research, dietary choline could increase the content of betaine, PC, and choline in fish skin. Results commend that the optimal choline increased choline content and corresponding metabolite in fish skin. In mammal enterocytes, choline can be transported though transport systems [9]. Such as, choline transporter-like proteins (CTLs) and high-affinity choline transporter ( $\mathrm{CHT} 1$ ) [9]. In this research, we found that optimal dietary choline up-regular the mRNA level of CTL2, CTL5, and HCT1, which indicated that skin absorbed choline through choline transporter CTL2, CTL5, and HCT1. Base on choline content and choline transporters mRNA abundance, the positive correlation was found in Table 5, we 
conjectured that the up-regular of those choline transporters mRNA abundance might be related to the increase of choline contents in fish skin. 
Table 5

Correlation analysis of parameters in the skin of juvenile grass carp (Ctenopharyngodon idella)

\begin{tabular}{|c|c|c|c|}
\hline Independent parameters & Dependent parameters & Correlation coefficients & $P$ \\
\hline \multirow[t]{3}{*}{ choline } & CTL2 & 0.981 & $<0.01$ \\
\hline & CTL5 & 0.959 & $<0.01$ \\
\hline & HCT1 & 0.927 & $<0.01$ \\
\hline \multirow[t]{6}{*}{ NF-kB P65 } & IL-1 $\beta$ & 0.986 & $<0.01$ \\
\hline & IFN-ץ2 & 0.981 & $<0.01$ \\
\hline & TNF-a & 0.91 & 0.012 \\
\hline & IL-6 & 0.932 & $<0.01$ \\
\hline & IL-12P40 & 0.982 & $<0.01$ \\
\hline & IL-15 & 0.86 & 0.028 \\
\hline \multirow[t]{6}{*}{ NF-kB P52 } & IL-1 $\beta$ & 0.994 & $<0.01$ \\
\hline & IFN-y2 & 0.991 & $<0.01$ \\
\hline & TNF-a & 0.956 & $<0.01$ \\
\hline & IL-6 & 0.952 & $<0.01$ \\
\hline & IL-12P40 & 0.996 & $<0.01$ \\
\hline & IL-15 & 0.906 & 0.013 \\
\hline \multirow[t]{6}{*}{ c-Rel } & IL-1 $\beta$ & 0.949 & $<0.01$ \\
\hline & IFN-y2 & 0.978 & $<0.01$ \\
\hline & TNF-a & 0.919 & $<0.01$ \\
\hline & IL-6 & 0.969 & $<0.01$ \\
\hline & IL-12P40 & 0.984 & $<0.01$ \\
\hline & IL-15 & 0.874 & 0.023 \\
\hline \multirow[t]{5}{*}{$\mathrm{lkBa}$} & NF-kB P65 & -0.92 & $<0.01$ \\
\hline & NF-kB P52 & -0.94 & $<0.01$ \\
\hline & c-Rel & -0.977 & $<0.01$ \\
\hline & $\mathrm{IKK} \beta$ & -875 & 0.022 \\
\hline & IKKy & -899 & 0.015 \\
\hline \multirow[t]{4}{*}{ STAT3b1 } & TGF- $\beta 1$ & 0.944 & $<0.01$ \\
\hline & IL-10 & 0.983 & $<0.01$ \\
\hline & IL-11 & 0.96 & $<0.01$ \\
\hline & IL-4/13A & 0.953 & $<0.01$ \\
\hline
\end{tabular}




\begin{tabular}{|llll|}
\hline Independent parameters & Dependent parameters & Correlation coefficients & $\boldsymbol{P}$ \\
\hline & IL-4/13B & 0.981 & $<0.01$ \\
\hline STAT3b2 & TGF- $\beta 1$ & 0.829 & 0.042 \\
& IL-10 & 0.95 & $<0.01$ \\
& IL-11 & 0.879 & 0.021 \\
\hline IL-4/13A & 0.96 & $<0.01$ \\
\hline JAK1 & IL-4/13B & 0.936 & $<0.01$ \\
\hline & STAT3b1 & 0.937 & $<0.01$ \\
\hline JAK2 & STAT3b2 & 0.966 & $<0.01$ \\
\hline & STAT3b1 & 0.92 & $<0.01$ \\
\hline & STAT3b2 & 0.968 & $<0.01$ \\
\hline
\end{tabular}

Striking, choline has no impact on the fish skin CTL4 mRNA abundant, which might be associated with ACh. CTL4 involved in the synthesis ACh in animals [34]. However, in our research, choline did not influence the ACh content of grass carp skin, which provides an important basis for our hypothesis.

\subsection{Dietary choline reduced skin lesion morbidity and enhanced immune function in the fish skin}

A. hydrophila is a potentially pathogenic bacteria that can cause fish skin lesion and even lead to death. [33]. Hence, after growth trail using A. hydrophila trail to study the skin lesion degree. Challenge with A. hydrophila, we found that dietary choline deficiency lead to the peak skin lesion morbidity (28.17\%), whereas sufficient choline abundance decreased skin lesion morbidity $(8.45 \%)$ in grass carp. Furthermore, the skin lesion resistance partially relies on skin immune response in fish [34]. These results declared that sufficient dietary choline reduced skin lesion morbidity. In fish, the immune function was mainly influenced by antimicrobial peptides such as LEAP-2 and hepcidin and humoral components like C4 and IgM [35]. The above results indicated that optimal dietary choline enhanced the ACP and LZ activities, C3, IgM, and C4 contents and increased mucin2, $\beta$-defensin LEAP-2B, and hepcidin mRNA abundance in the fish skin. These results investigated that choline addition heightened the immune function in fish. The concentration of C4 in the optimal choline supplementation group was 3.39 - fold that of the $142.2 \mathrm{mg} / \mathrm{kg}$ choline group, which was significantly higher than other enzyme activities and C3 content (1.36- to 1.89-fold). This indicates that the regulation of $\mathrm{C} 4$ by choline is more active and effective.

Interesting, considering the differences between the vitamins mentioned in the introduction, we compared choline with VB7 and a-lipoic acid[8, 36]. Unlike two other vitamins, choline deficiency did not affect LEAP-2A mRNA level, which might be partly relevant to IKKa. IKKa improved IL-22 level in mice[37], which enhanced LEAP-2A mRNA abundance in rainbow trout splenocytes[38]. However, in this research, choline supplementation did not affect IKKa mRNA abundance in fish skin, which might support our hypothesis. Moreover, these data also illustrated that LEAP-2A might be higher conscious by VB7, and a-lipoic acid in fish skin than dietary choline.

\subsection{Dietary choline enhanced immune function referring to the mRNA abundance of inflammatory factors in the fish skin}


Inflammation is a host defense mechanism, but overregulation of the inflammatory response disrupts the balance of immune function, leading to the deterioration of human diseases [37].Morimoto et al. observed that the inflammatory function of fish immune organs was affect by inflammatory cytokines [39]. However, no research has studied the impacts of choline addition on inflammatory response in fish skin. In this research, we were the first time investigated that choline addition decreased the mRNA level of proinflammatory cytokines IFN- 2 2, TNF-a, IL-15, IL-12p40, IL-6, and IL-1 $\beta$ and up-regular the mRNA abundance of anti-inflammatory cytokines TGF- $\beta 1$, IL-11, IL-10, and IL-4/13A in the grass carp skin. In short, all of the above results illustrated that dietary choline supplement improved the immune function in fish skin.

Interesting, the potential reasons for differential result are discussed as follows. First, our previous research found that appropriate dietary VB7 could descend the mRNA abundance of IL-12p35 (rather than IL-12p40)[8]. While, in our study, appropriate choline increased of fish skin IL-12p40 (not IL-12p35) mRNA abundance. This result might be related to TNF-a. In this research, appropriate dietary choline downregulated TNF-a mRNA levels in grass carp skin. In Atlantic salmon HK cells, TNF-a could increase the IL-12p40 (not IL-12p35) gene level [40], which supports our speculation. Moreover, these data also indicated that choline and VB7 had different regulatory mechanism between different subtypes of the same gene (such as IL-12p35 and IL-12p40). Second, dietary a-lipoic acid and VB7 decreased the mRNA abundant of IL-17D, but dietary choline did not influence the IL-17D mRNA abundant in fish skin was might be relevant to tryptophan. Tryptophan catabolites could inhibit the production of IL-17 in mice[41]. Previous studies have found that choline did not affect the content of tryptophan in the intestine[19], which might support our hypothesis and needs further investigation. In addition, these data also indicated that IL-17D is more easily regulated by dietary choline rather than a-lipoic acid and VB7 in fish skin. Third, choline insufficient did not influence the TGF- $\beta 2$ mRNA abundant in fish skin, which might be partly related to methionine. Methionine regeneration was mediated by choline in bovine neonatal hepatocytes [42]. Methionine dipeptide supplementation has no impact on the TGF- $\beta 2$ mRNA abundance of grass carp intestine[43], which needs further study. Moreover, previous studies found that dietary a-lipoic acid could upregulate the mRNA abundant of TGF- $\beta 2$, indicated that TGF- $\beta 2$ is more easily regulated by dietary a-lipoic acid rather than choline in fish skin.

\subsection{Dietary choline enhanced immune function referring to JAK/STAT3 and NF-KB singaling molecules in the fish skin}

A previous study had found that inflammatory response is related to the mRNA expression of proinflammatory cytokines in fish[44]. Proinflammatory cytokines were regulated by the transcription factor NF-kB, like NF-kB p65 and p52 were inhibited by IkBa in mammalian cell[45].Our data showed that the proinflammatory cytokines (IFN- $\gamma 2$, IL1 $\beta$, IL6 , TNF-a, IL-12p40, and IL-15) mRNA abundance was down-regulated by optimal dietary choline in grass carp skin, implying that optimal dietary choline enhanced inflammatory function in fish skin. Furthermore, optimal dietary choline restrained the NF-KB signaling pathway by activated the IKBa protein level and decrease nuclear NFKBp65 protein level, as well as c-Rel, IKK 3, NF-KBp65, IKKy, and NF-KBp52 (not IKKa) mRNA abundance in grass carp skin. C-Rel, NF-KB p52, and NF-kBp65 mRNA abundance was positively correlated the pro-inflammatory cytokines mRNA abundance which showed in Table 5. As the same time, c-Rel, NF-KB p52, and NF-KB p65 mRNA abundance was positively related with IKK $\beta$ and IKKY mRNA abundance, which were inverse correlation with the IKBa mRNA abundance. These data elucidated that the optimal dietary choline down-regular the proinflammatory cytokines mRNA abundance might be relevant to $\mathrm{IKK} \beta$ and $\mathrm{IKK} Y / \mathrm{IKBa} / \mathrm{NF}-\mathrm{KB}$ signaling in the fish skin.

STAT3 signaling pathway plays an important role in promoting the gene expressions of anti-inflammatory cytokines in humans[6]. STAT3 is also a member of the STAT family, which can be activated by the upstream signaling molecule Janus kinases (e.g., JAK2)[46]. In this research, we were the first time investigated that choline addition increased the mRNA abundance of STAT3b1, STAT3b2, JAK1, and JAK2, as well as p-STAT3 Tyr705 protein level in fish skin (Fig. 5), which implying that dietary choline up-regulated most of anti-inflammatory cytokines might be partly related to STAT3 
signaling pathway. Correlation analyses (Table 5) showed that anti-inflammatory cytokines (IL-10, TGF- $\beta 1$, IL-4/13A, IL11, and IL-4/13B) were positively correlated with the STAT3b1and STAT3b2 mRNA abundance in fish skin. Our data showed that weaken effect of the anti-inflammatory by dietary choline might be relevant to JAK1, JAK2/STAT3 signaling in grass carp skin.

Interestingly, choline has no impact on IKKa mRNA abundant of grass carp skin, which may be relevant to IFN- $\gamma$. This research indicated that dietary choline deficiency increased fish skin IFN- $\gamma$ mRNA abundance. In U937 cells, IFN- $\gamma$ enhanced protein kinase C C level[47], which increased IKK 3 and IKKY (not IKKa) gene abundance in Kupffer cells [48] Further research is needed to confirm this hypothesis. Similar phenomena were discovered in VB7, and a-lipoic acid from our previous research in grass carp skin, which may illustrate that vitamins B is not sensitivity enough to IKKa in skin. Moreover, in human myeloid cells, macrophage colony stimulating factor (GM-CSF) could activate STAT3b (rather than STAT3a)[49]. However, choline supplementation had no effect on GM-CSF concentrations in rat placenta[50]. Therefore, we speculated that choline deficiency down-regulated STAT3b1/b2 rather than STAT3a gene expressions in fish skin may be caused by the decrease of GM-CSF. Further research is needed to confirm this hypothesis.

\subsection{Choline requirements based on immune indices}

Appropriate choline group advanced most of inflammatory indicators and receded skin lesion. Further, based on the skin immune indices (C3 and IgM contents as well as ACP activities) the choline requirements for grass carp (9.28$108.97 \mathrm{~g}$ ) were estimated to be $1475.81,1364.24$, and $1574.37 \mathrm{mg} / \mathrm{kg}$ diet, respectively. The requirements for the majority of the skin immune index were higher than those for the growth (feed efficiency $1283.4 \mathrm{mg} / \mathrm{kg} \mathrm{diet)} \mathrm{[19].}$ Similar results was found in other vitamins like VB7 and VC in grass carp $[8,18]$. This result may illustrate that more choline or metabolites was needed for fish to resistance to bacterial infection.

\section{Conclusions}

Summary above, we reveal four primaries, innovative, and interesting results. The results exhibited that dietary choline (1) advanced contents of choline, betaine, and PC (not ACh) in grass crap skin $(P<0.05)$, down-regulated the mRNA abundance of choline transporter CHT1, CTL1, and CTL5 (rather than CTL2 and CTL4) indicating that dietary choline could increase the contents of choline and its metabolites as well as choline transporters expression in the skin; (2) reduced skin lesion and increased the contents of $\mathrm{C} 3$, IgM, C4, and the activities of ACP and LZ, advanced mucin2, LEAP-2B, hepcidin, and $\beta$-defensin mRNA abundance (rather than LEAP-2A), up-regulated the mRNA abundance of IL$1 \beta$, IFN- $\gamma 2$, TNF- $a$, IL-6, IL-12P40, and IL-15 (rather than IL-12P35 and IL-17) in skin of juvenile grass carp $(P<0.05)$, down-regulated the mRNA abundance of TGF- $\beta 1$, IL-4/13A, IL-4/13B IL-11 and IL-10 (rather than TGF- $\beta 2$ ) in grass crap skin $(P<0.05)$ showed that choline enhanced the immune function of the skin; (3) down-regulated the mRNA abundance of IKKY, IKKB, c-Rel, NF-KBp65, and NF-KBp52 as well as protein level of NF-KBp65 in nucleus, up-regulated the mRNA and protein level of $\mathrm{kBBa}$, advanced the mRNA abundance of STAT3b1, STAT3b2, JAK1, and JAK2 ( rather than JAK3, STAT3a) as well as p-STAT3 Tyr705 protein level in grass crap skin $(P<0.05)$, indicating that choline protected immune function might relate to JAK/STAT3 and NF-KB singaling pathway in fish skin; In conclusion, choline enhanced the skin immune function be relevant to JAK/STAT3 and NF-KB signaling molecules in fish. Furthermore, based on the skin immune indices (C3 and IgM contents as well as ACP activities) the choline requirements for grass carp (9.28-108.97 g) were estimated to be 1475.81, 1364.24, and $1574.37 \mathrm{mg} / \mathrm{kg}$ diet, respectively.

\section{Abbreviations}

PC: phosphatidylcholine; ACP: acid phosphatase; LZ: lysozyme activity; JAK: Janus kinases; STAT: signal transducer and activator of transcription; IgM: Immunoglobulin M; ACP:Acid phosphatase; TNF-a: tumor necrosis factor-a; ACh: 
acetylcholine; NF-kB: nuclear factor kappa-B; ECL: electrochemiluminescence; LEAP2: liver-expressed antimicrobial peptide2; IFN- $\gamma$ : interferon $\gamma ;$ TGF- $\beta$ : transforming growth factor- $\beta$; CTLs: choline transporter-like proteins; $C H T 1$ : highaffinity choline transporter; GM-CSF: macrophage colony stimulating factor;

\section{Declarations}

\section{Acknowledgments}

Not applicable.

\section{Funding}

This research was financially supported by National Natural Science Foundation of China (31772866), National Key R\&D Program of China (2019YFD0900200, 2018YFD0900400), National Natural Science Foundation of China for Outstanding Youth Science Foundation (31922086), the Young Top-Notch Talent Support Program of National TenThousand Talents Program, the Earmarked Fund for China Agriculture Research System (CARS-45), Outstanding Talents and Innovative Team of Agricultural Scientific Research (Ministry of Agriculture), Key Research and Development Plan in Sichuan Province (2018NZ0007), and Supported by Sichuan Science and Technology Program (2019YFN0036). The authors would like to express their sincere thanks to the personnel of these teams for their kind assistance.

\section{Availability of data and materials}

All data generated or analysed during this study are included in this published article.

\section{Authors' contributions}

Zehong Yuan performed formal analysis, investigation and writing - original draft.

Lin Feng performed conceptualization, methodology, validation, data curation and project administration.

Weidan Jiang performed data curation, validation, project administration and writing - review \& editing

Pei Wu performed conceptualization, funding acquisition and resources.

Yang Liu performed project administration.

Shengyao Kuang and Ling Tang performed resources.

Xiaoqiu Zhou performed conceptualization, methodology, supervision, funding acquisition and supervision.

\section{Ethics approval}

All procedures used in this study were approved by the Institutional Animal Care and Use Committee of Sichuan Agricultural University. We followed guidelines of the Committee for experimental animal during this study.

\section{Consent for publication}

Not applicable.

\section{Competing interests}


The authors declare that they have no competing interests.

\section{Author details}

1 Animal Nutrition Institute, Sichuan Agricultural University, Chengdu 611130, China

2 Fish Nutrition and Safety Production University Key Laboratory of Sichuan Province, Sichuan Agricultural University, Chengdu 611130, China

3 Key Laboratory for Animal Disease-Resistance Nutrition of China Ministry of Education, Sichuan Agricultural University, Chengdu 611130, Sichuan, China

4 Animal Nutrition Institute, Sichuan Academy of Animal Science, Chengdu 610066, China

\section{References}

1. Wang XZ, Jiang WD, Feng L, Wu P, Liu Y, Zeng YY, et al. Low or excess levels of dietary cholesterol impaired immunity and aggravated inflammation response in young grass carp (Ctenopharyngodon idella). Fish Shellfish Immunol. 2018;78:202-21. Epub 2018/04/24. doi: 10.1016/j.fsi.2018.04.030. PubMed PMID: 29684613.

2. Pohlenz C, Gatlin DM. Interrelationships between fish nutrition and health. Aquaculture. 2014;431:111-7.

3. Evans DH, Piermarini PM, Choe KP. The Multifunctional Fish Gill: Dominant Site of Gas Exchange, Osmoregulation, Acid-Base Regulation, and Excretion of Nitrogenous Waste. Physiological Reviews. 2005;85(1):97-177. doi: 10.1152/physrev.00050.2003.

4. Koppang EO, Kvellestad A, Fischer U. Fish mucosal immunity: gill. Mucosal Health in Aquaculture2015. p. 93-133.

5. Zhao HF, Jiang WD, Liu Y, Jiang J, Wu P, Kuang SY, et al. Dietary choline regulates antibacterial activity, inflammatory response and barrier function in the gills of grass carp (Ctenopharyngodon idella). Fish \& shellfish immunology. 2016;52:139-50. doi: 10.1016/j.fsi.2016.03.029. PubMed PMID: 26988287.

6. Murray PJ. Understanding and exploiting the endogenous interleukin-10/STAT3-mediated anti-inflammatory response. Current Opinion in Pharmacology. 2006;6(4):379-86.

7. Zheng L, Feng L, Jiang WD, Wu P, Tang L, Kuang SY, et al. Selenium deficiency impaired immune function of the immune organs in young grass carp (Ctenopharyngodon idella). Fish \& shellfish immunology. 2018;77:53-70. Epub 2018/03/22. doi: 10.1016/j.fsi.2018.03.024. PubMed PMID: 29559270.

8. He P, Jiang WD, Liu XA, Feng L, Wu P, Liu Y, et al. Dietary biotin deficiency decreased growth performance and impaired the immune function of the head kidney, spleen and skin in on-growing grass carp (Ctenopharyngodon idella). Fish Shellfish Immunol. 2020;97:216-34. Epub 2019/12/21. doi: 10.1016/j.fsi.2019.12.033. PubMed PMID: 31857225.

9. Horie A, Ishida K, Watanabe Y, Shibata K, Hashimoto Y. Membrane transport mechanisms of choline in human intestinal epithelial LS180 cells. Biopharmaceutics \& Drug Disposition. 2014;35(9):532-42.

10. Ueland PM. Choline and betaine in health and disease. Journal of Inherited Metabolic Disease. 2011;34(1):3-15.

11. Hasanzadeh-Moghadam M, Khadem-Ansari MH, Farjah GH, Rasmi Y. Hepatoprotective effects of betaine on liver damages followed by myocardial infarction. Vet Res Forum. 2018;9(2):129-35. Epub 2018/08/02. doi: 10.30466/vrf.2018.30834. PubMed PMID: 30065801; PubMed Central PMCID: PMCPMC6047573.

12. Tabassum S, Haider S, Ahmad S, Madiha S, Parveen T. Chronic choline supplementation improves cognitive and motor performance via modulating oxidative and neurochemical status in rats. Pharmacology, Biochemistry and Behavior. 2017;159:90-9. 
13. Marrero MB, Bencherif M. Convergence of alpha 7 nicotinic acetylcholine receptor-activated pathways for antiapoptosis and anti-inflammation: central role for JAK2 activation of STAT3 and NF-kappaB. Brain Res. 2009;1256:1-7. Epub 2008/12/10. doi: 10.1016/j.brainres.2008.11.053. PubMed PMID: 19063868.

14. Treede I, Braun A, Sparla R, Kuhnel M, Giese T, Turner JR, et al. Anti-inflammatory effects of phosphatidylcholine. Journal of Biological Chemistry. 2007;282(37):27155-64.

15. Yan J, Jiang X, West AA, Perry CA, Malysheva OV, Brenna JT, et al. Pregnancy alters choline dynamics: results of a randomized trial using stable isotope methodology in pregnant and nonpregnant women. Am J Clin Nutr. 2013;98(6):1459-67. Epub 2013/10/18. doi: 10.3945/ajcn.113.066092. PubMed PMID: 24132975; PubMed Central PMCID: PMCPMC6410899.

16. Jiang WD, Zhang L, Feng L, Wu P, Liu Y, Jiang J, et al. Inconsistently impairment of immune function and structural integrity of head kidney and spleen by vitamin A deficiency in grass carp (Ctenopharyngodon idella). Fish Shellfish Immunol. 2020;99:243-56. Epub 2020/02/15. doi: 10.1016/j.fsi.2020.02.019. PubMed PMID: 32058097.

17. Khosravi S, Jang J, Rahimnejad S, Song J, Lee K. Choline Essentiality and Its Requirement in Diets for Juvenile Parrot Fish (Oplegnathus fasciatus). Asian-australasian Journal of Animal Sciences. 2015;28(5):647-53.

18. Xu HJ, Jiang WD, Feng L, Liu Y, Wu P, Jiang J, et al. Dietary vitamin C deficiency depresses the growth, head kidney and spleen immunity and structural integrity by regulating NF-kappaB, TOR, Nrf2, apoptosis and MLCK signaling in young grass carp (Ctenopharyngodon idella). Fish Shellfish Immunol. 2016;52:111-38. Epub 2016/03/06. doi: 10.1016/j.fsi.2016.02.033. PubMed PMID: 26944716.

19. Yuan Z-H, Feng L, Jiang W-D, Wu P, Liu Y, Jiang J, et al. Choline deficiency decreased the growth performances and damaged the amino acid absorption capacity in juvenile grass carp (Ctenopharyngodon idella). Aquaculture. 2020;518. doi: 10.1016/j.aquaculture.2019.734829.

20. Ni PJ, Jiang WD, Wu P, Liu Y, Kuang SY, Tang L, et al. Dietary low or excess levels of lipids reduced growth performance, and impaired immune function and structure of head kidney, spleen and skin in young grass carp (Ctenopharyngodon idella) under the infection of Aeromonas hydrophila. Fish Shellfish Immunol. 2016;55:28-47. Epub 2016/05/10. doi: 10.1016/j.fsi.2016.03.163. PubMed PMID: 27157598.

21. Khan MA, Jafri AK, Chadha NK. Growth, reproductive performance, muscle and egg composition in grass carp, Ctenopharyngodon idella (Valenciennes), fed hydrilla or formulated diets with varying protein levels. Aquaculture Research. 2004;35(13):1277-85. doi: 10.1111/j.1365-2109.2004.01150.x.

22. Xu HJ, Jiang WD, Feng L, Liu Y, Wu P, Jiang J, et al. Dietary vitamin C deficiency depressed the gill physical barriers and immune barriers referring to Nrf2, apoptosis, MLCK, NF-kappaB and TOR signaling in grass carp (Ctenopharyngodon idella) under infection of Flavobacterium columnare. Fish Shellfish Immunol. 2016;58:177-92. Epub 2016/10/23. doi: 10.1016/j.fsi.2016.09.029. PubMed PMID: 27640333.

23. Ding Y, Mou S. Determination of Choline Chloride and Trimethylamine in Feedstuff by lon Chromatography. Se pu = Chinese journal of chromatography / Zhongguo hua xue hui. 2004;22(2):174.

24. Wu P, Feng L, Kuang S-Y, Liu Y, Jiang J, Hu K, et al. Effect of dietary choline on growth, intestinal enzyme activities and relative expressions of target of rapamycin and elF4E-binding protein2 gene in muscle, hepatopancreas and intestine of juvenile Jian carp (Cyprinus carpio var. Jian). Aquaculture. 2011;317(1-4):107-16. doi: 10.1016/j.aquaculture.2011.03.042.

25. Feng L, Xiao WW, Liu Y, Jiang J, Hu K, Jiang WD, et al. Methionine hydroxy analogue prevents oxidative damage and improves antioxidant status of intestine and hepatopancreas for juvenile Jian carp (Cyprinus carpio var. Jian). Aquaculture Nutrition. 2011;17(6):595-604. doi: 10.1111/j.1365-2095.2011.00853.x.

26. Hong Y, Jiang W, Kuang S, Hu K, Tang L, Liu Y, et al. Growth, digestive and absorptive capacity and antioxidant status in intestine and hepatopancreas of sub-adult grass carp Ctenopharyngodonidella fed graded levels of

Page $17 / 23$ 
dietary threonine. J Anim Sci Biotechnol. 2015;6(1):34. Epub 2015/08/11. doi: 10.1186/s40104-015-0032-1. PubMed PMID: 26257911; PubMed Central PMCID: PMCPMC4529687.

27. Zhong JR, Feng L, Jiang WD, Wu P, Liu Y, Jiang J, et al. Phytic acid disrupted intestinal immune status and suppressed growth performance in on-growing grass carp (Ctenopharyngodon idella). Fish Shellfish Immunol. 2019;92:536-51. Epub 2019/06/28. doi: 10.1016/j.fsi.2019.06.045. PubMed PMID: 31247320.

28. Takemura A. Changes in an immunoglobulin M (IgM)-like protein during larval stages in tilapia, Oreochromis mossambicus. Aquaculture. 1993;115:233-41.

29. Huang C, Feng L, Jiang WD, Wu P, Liu Y, Zeng YY, et al. Deoxynivalenol decreased intestinal immune function related to NF-kappaB and TOR signalling in juvenile grass carp (Ctenopharyngodon idella). Fish Shellfish Immunol. 2019;84:470-84. Epub 2018/10/20. doi: 10.1016/j.fsi.2018.10.039. PubMed PMID: 30339843.

30. Wang K, Zhu X, Li Y, Chen D, Wu P, Chu W. Molecular characterization and expression regulation of Smyd1a and Smyd1b in skeletal muscle of Chinese perch ( Siniperca chuatsi). Comparative Biochemistry \& Physiology Part B Biochemistry \& Molecular Biology. 2016;194-195:25-31.

31. Dong YW, Jiang WD, Liu Y, Wu P, Jiang J, Kuang SY, et al. Threonine deficiency decreased intestinal immunity and aggravated inflammation associated with NF-kappaB and target of rapamycin signalling pathways in juvenile grass carp (Ctenopharyngodon idella) after infection with Aeromonas hydrophila. The British journal of nutrition. 2017;118(2):92-108. Epub 2017/08/19. doi: 10.1017/S0007114517001830. PubMed PMID: 28820083.

32. Renna M. Evaluation of the suitability of a partially defatted black soldier fly (Hermetia illucens L.) larvae meal as ingredient for rainbow trout (Oncorhynchus mykiss Walbaum) diets. Journal of Animal Science and Biotechnology. 2017;(8:57). doi: 10.1186/s40104-017-0191-3.

33. Ji Y, Luo X, Yang Y, Dai Z, Wu G, Wu Z. Endoplasmic reticulum stress-induced apoptosis in intestinal epithelial cells: a feed-back regulation by mechanistic target of rapamycin complex 1 (mTORC1). J Anim Sci Biotechnol. 2018;9:38. Epub 2018/05/11. doi: 10.1186/s40104-018-0253-1. PubMed PMID: 29744053; PubMed Central PMCID: PMCPMC5932775.

34. Song P, Rekow SS, Singleton C, Sekhon HS, Dissen GA, Zhou M, et al. Choline transporter-like protein 4 (CTL4) links to non-neuronal acetylcholine synthesis. Journal of Neurochemistry. 2013;126(4):451-61.

35. Li M, Feng L, Jiang WD, Wu P, Liu Y, Jiang J, et al. Condensed tannins decreased the growth performance and impaired intestinal immune function in on-growing grass carp (Ctenopharyngodon idella). Br J Nutr. 2020;123(7):737-55. Epub 2019/12/14. doi: 10.1017/S0007114519003295. PubMed PMID: 31831090.

36. Liu HX, Zhou XQ, Jiang WD, Wu P, Liu Y, Zeng YY, et al. Optimal alpha-lipoic acid strengthen immunity of young grass carp (Ctenopharyngodon idella) by enhancing immune function of head kidney, spleen and skin. Fish Shellfish Immunol. 2018;80:600-17. Epub 2018/07/19. doi: 10.1016/j.fsi.2018.06.057. PubMed PMID: 30018021.

37. Giacomin PR, Moy RH, Noti M, Osborne LC, Siracusa MC, Alenghat T, et al. Epithelial-intrinsic IKKa expression regulates group 3 innate lymphoid cell responses and antibacterial immunity. Journal of Experimental Medicine. 2015;212(10):1513-28.

38. Monte MM, Zou J, Wang T, Carrington A, Secombes CJ. Cloning, expression analysis and bioactivity studies of rainbow trout (Oncorhynchus mykiss) interleukin-22. Cytokine. 2011;55(1):62-73.

39. Morimoto T, Biswas G, Kono T, Sakai M, Hikima J. Immune responses in the Japanese pufferfish (Takifugu rubripes) head kidney cells stimulated with particulate silica. Fish \& Shellfish Immunology. 2016;49:84-90.

40. Wang T, Husain M. The expanding repertoire of the IL-12 cytokine family in teleost fish: Identification of three paralogues each of the p35 and p40 genes in salmonids, and comparative analysis of their expression and modulation in Atlantic salmon Salmo salar. Dev Comp Immunol. 2014;46(2):194-207. Epub 2014/04/25. doi: 10.1016/j.dci.2014.04.008. PubMed PMID: 24759618.

Page 18/23 
41. Kolodziej L. Systemic metabolism of tryptophan and its catabolites, kynurenine and 3-HAA, in mice with inflammatory arthritis. Gene. 2013;512(1):23-7. Epub 2012/10/16. doi: 10.1016/j.gene.2012.09.122. PubMed PMID: 23063938.

42. Chandler TL, White HM. Choline and methionine differentially alter methyl carbon metabolism in bovine neonatal hepatocytes. PLOS ONE. 2017;12(2).

43. Su YN, Wu P, Feng L, Jiang WD, Jiang J, Zhang YA, et al. The improved growth performance and enhanced immune function by DL-methionyl-DL-methionine are associated with NF-kappaB and TOR signalling in intestine of juvenile grass carp (Ctenopharyngodon idella). Fish Shellfish Immunol. 2018;74:101-18. Epub 2018/01/03. doi: 10.1016/j.fsi.2017.12.051. PubMed PMID: 29292200.

44. Sun H, Jiang W-D, Wu P, Liu Y, Jiang J, Yang Q-H, et al. Betaine supplementations enhance the intestinal immunity of on-growing grass carp (Ctenopharyngodon idella): Partly related to TOR and NF-KB signaling pathways. Aquaculture. 2020;518. doi: 10.1016/j.aquaculture.2019.734846.

45. Vallabhapurapu S, Karin M. Regulation and Function of NF-kB Transcription Factors in the Immune System. Annual Review of Immunology. 2009;27(1):693-733.

46. De Jonge WJ, Der Zanden EPV, Bijlsma MF, Van Westerloo DJ, Bennink RJ, Berthoud H, et al. Stimulation of the vagus nerve attenuates macrophage activation by activating the Jak2-STAT3 signaling pathway. Nature Immunology. 2005;6(8):844-51.

47. A. J. MELENDEZ MMHJMA. Differentiation-dependent switch in protein kinase $\mathrm{C}$ isoenzyme activation by FccRI, the human high-affınity receptor for immunoglobulin G. Immunology 1999;96:457-64.

48. Peng Y, Sigua CA, Gallagher SF, Murr MM. Protein kinase C-zeta is critical in pancreatitis-induced apoptosis of Kupffer cells. J Gastrointest Surg. 2007;11(10):1253-61. Epub 2007/07/27. doi: 10.1007/s11605-007-0193-0. PubMed PMID: 17653813.

49. Arup Chakraborty SMW, Timothy S. Schaefer, Edward D. Ball, Kevin F. Dyer, and David J. Tweardy. Granulocyte Colony-Stimulating Factor Activation of Stat3a and Stat3P in Immature Normal and Leukemic Human Myeloid Cells.RAPID COMMUNICATION. 1996;88:2442-9.

50. Zhang M, Han X, Bao J, Yang J, Shi S, Garfield RE, et al. Choline Supplementation During Pregnancy Protects Against Gestational Lipopolysaccharide-Induced Inflammatory Responses. Reproductive Sciences. 2018;25(1):7485.

\section{Figures}


B.
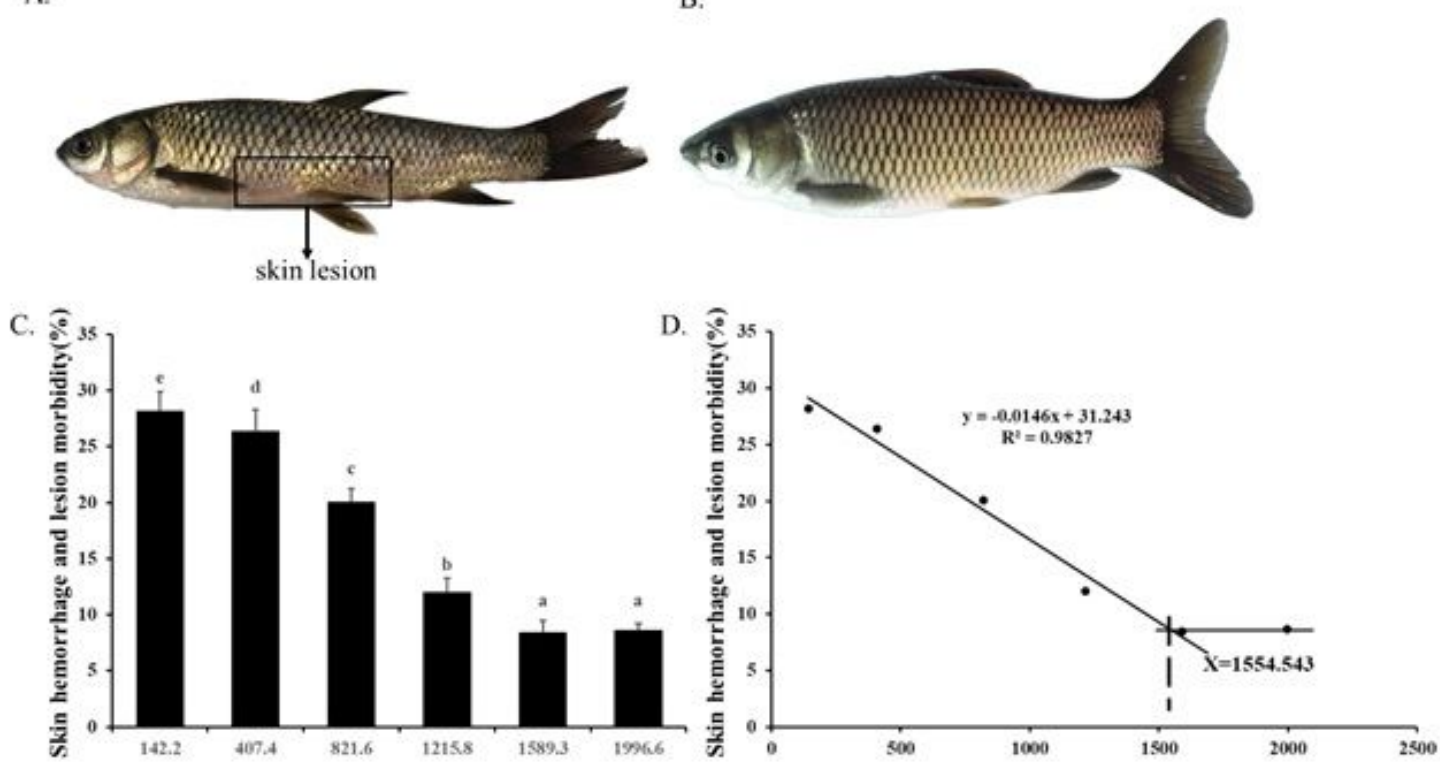

Figure 1

Effects of dietary choline level ( $\mathrm{mg} / \mathrm{kg}$ diet) on skin rot morbidity of juvenile grass carp. Ctenopharyngodon idella) after infection with A. hydrophila. (A) $142.2 \mathrm{mg} / \mathrm{kg}$ diet. (B) $1589.3 \mathrm{mg} / \mathrm{kg}$ diet. *P-values underlined with a solid line indicate a significant linear dose response relationship $(P<0.05)$. Values are means, and standard error of the mean represented by vertical bars. $N=6 * 5$ for each choline level. Values having different letters are significantly different $(P<0.05)$.

\section{Dietary choline level (mg/kg diet)}

口 $142.2 \square 407.4 \quad 821.6 \square 1215.8$ 目 $1589.3 \quad 1996.6$

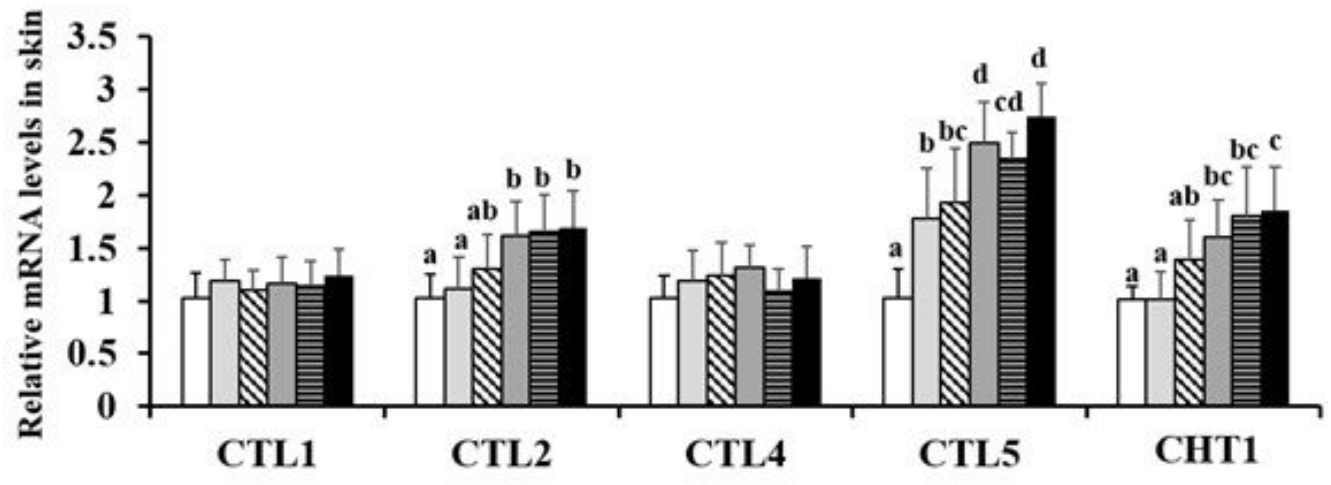

Figure 2

Effects of dietary choline on choline transporter gene level in the intestine of juvenile grass carp (Ctenopharyngodon idella) after infection with A. hydrophila. Data represent means of six fish in each group, error bars indicate S.D. Values having different letters are significantly different $(P<0.05)$. 
A.

Dietary choline level ( $\mathrm{mg} / \mathrm{kg}$ diet)
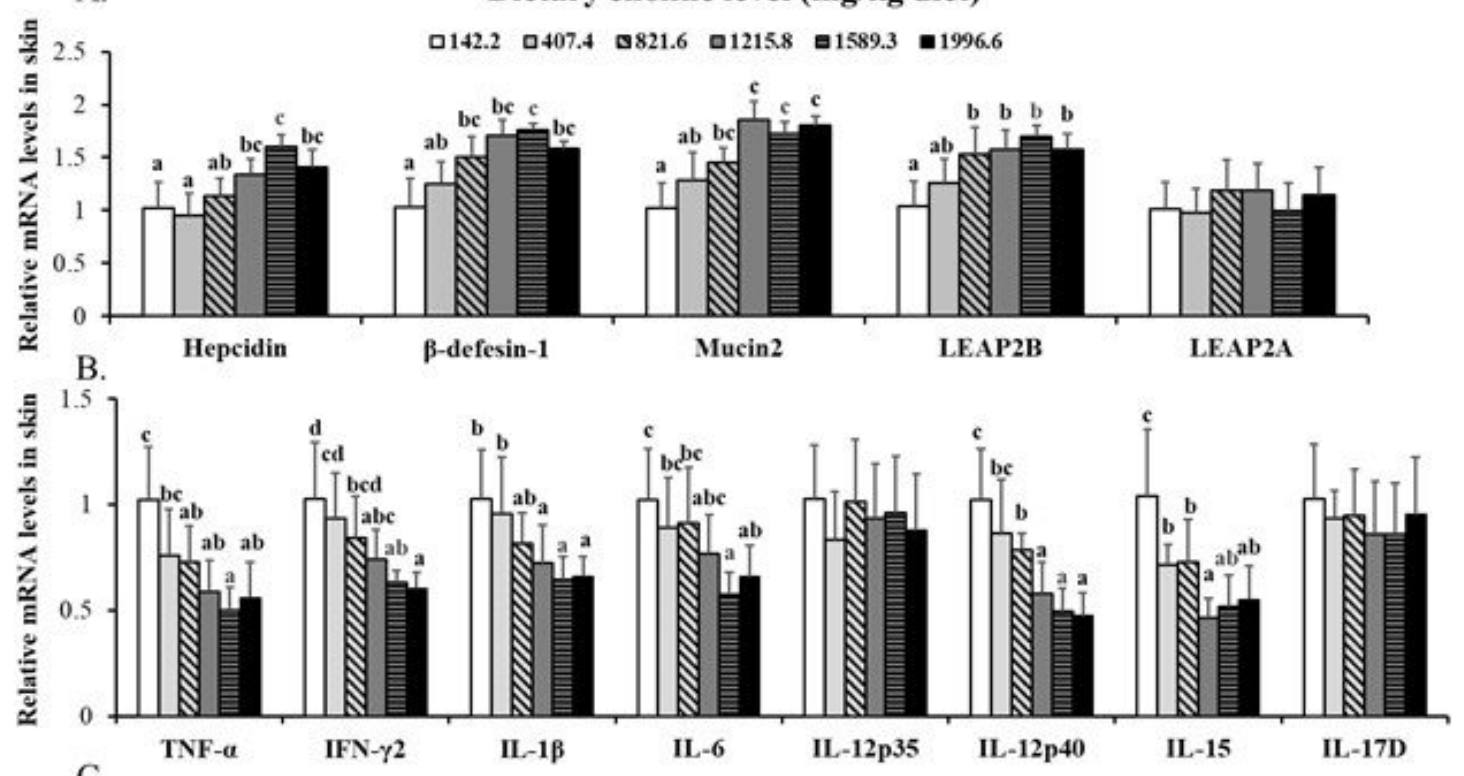

C.

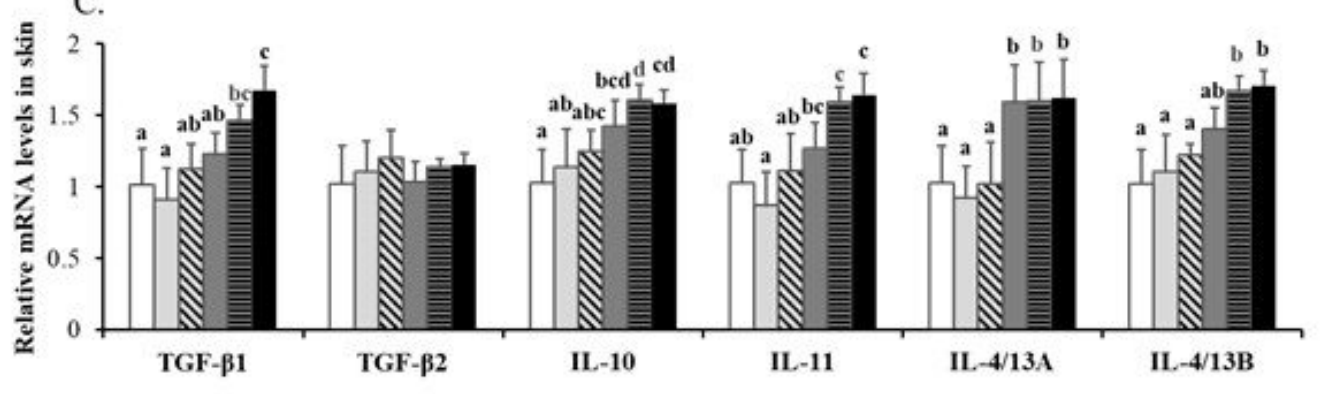

Figure 3

Effects of dietary choline on parameters mRNA levels in the skin of grass carp after infection with A. hydrophila. This analysis was repeated 6 times with similar results. Data represent means of six fish in each group, error bars indicate S.D. Values having different letters are significantly different $(P<0.05)$.

Dietary choline level (mg/kg diet)

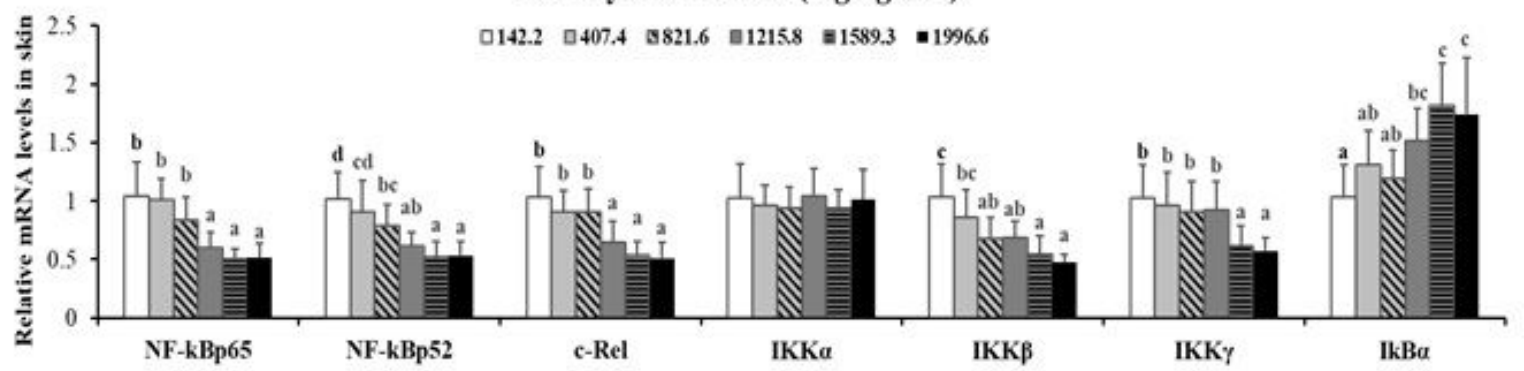

\section{Figure 4}

Effects of dietary choline level (mg/kg diet) on relative expression of NF-KB signaling molecules in skin of juvenile grass carp (Ctenopharyngodon idella) after infection with A. hydrophila. Data represent means of six fish in each group, error bars indicate S.D. Values having different letters are significantly different $(P<0.05)$. 
Dietary choline level $(\mathrm{mg} / \mathrm{kg}$ diet)

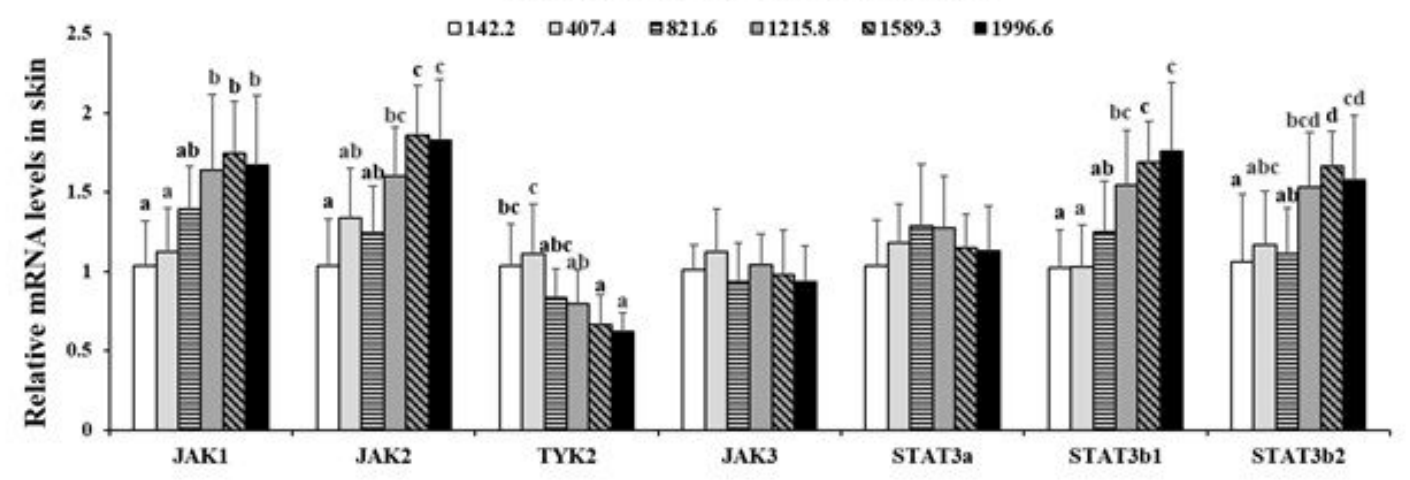

Figure 5

Effects of dietary choline level ( $\mathrm{mg} / \mathrm{kg}$ diet) on relative expression of JAK/STAT3 in skin of juvenile grass carp (Ctenopharyngodon idella) after infection with A. hydrophila. Data represent means of six fish in each group, error bars indicate S.D. Values having different letters are significantly different $(P<0.05)$.

A.

\section{Dietary choline levels ( $\mathrm{mg} / \mathrm{kg}$ dietary)}

$\begin{array}{llllll}142.2 & 407.4 & 821.6 & 1215.8 & 1589.3 & 1996.6\end{array}$

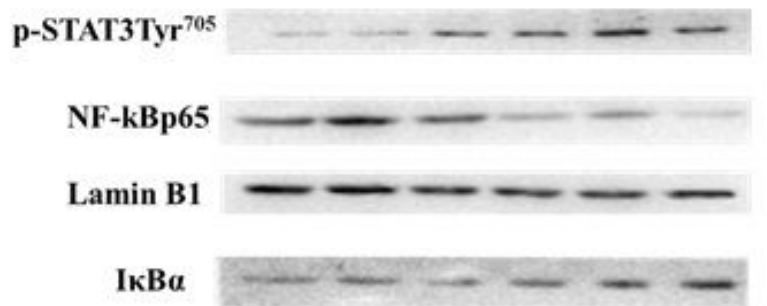

$\beta$-actin
B.
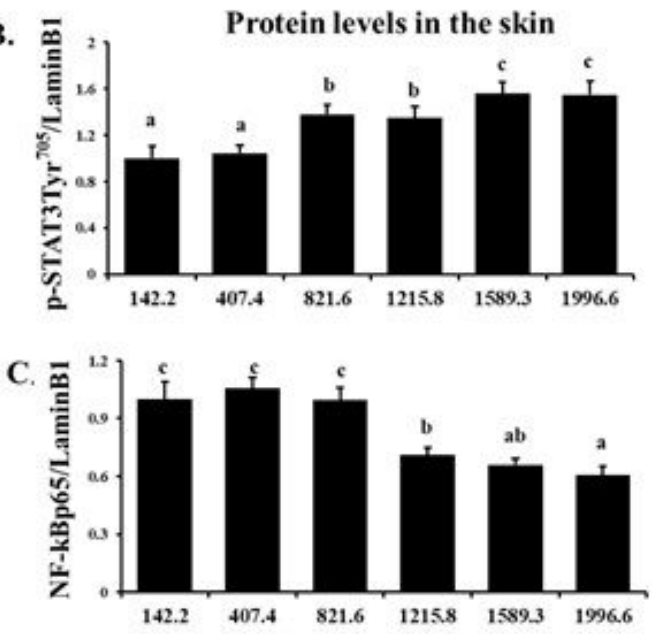

D.

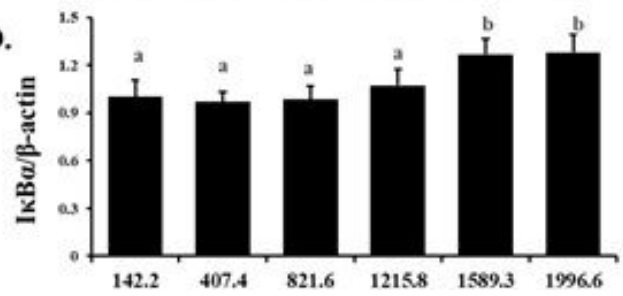

Figure 6

Western blot analysis of p-STAT3Tyr705, NF-KBp65, and IкBa protein level in the skin of juvenile grass carp fed diet containing different levels of choline after infection with A. hydrophila. Values are means (6 replicates per group), and standard error represented by vertical bars. a,b,c Mean values with unlike letters were significantly different between treatments $(P<0.05)$ 

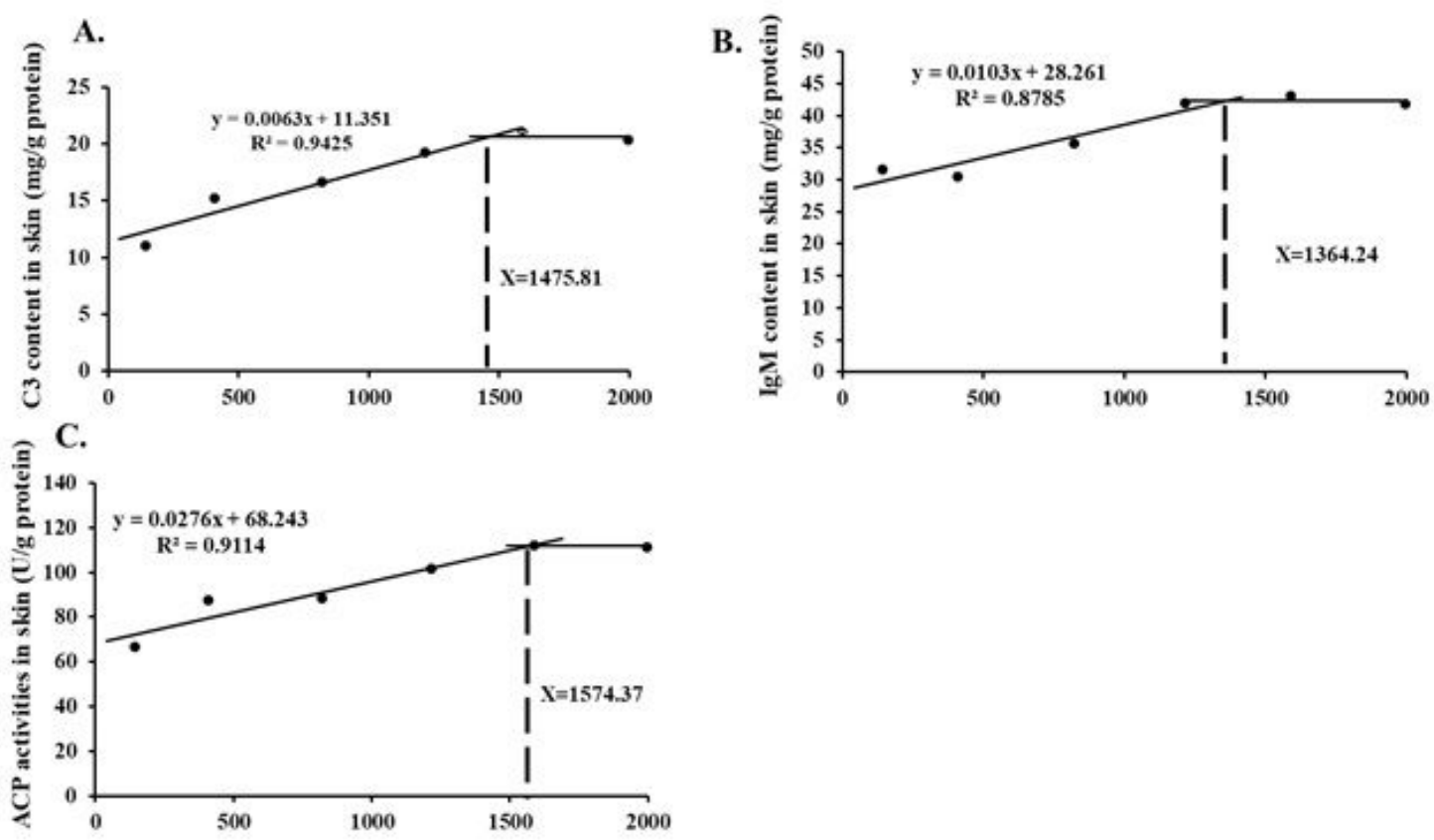

\section{Figure 7}

Broken-line analysis of $\mathrm{C} 3(\mathrm{~A})$, $\lg \mathrm{M}(\mathrm{B})$, and $\mathrm{ACP}$ content (C) in skin for grass carp (Ctenopharyngodon idella) fed diets containing graded levels of choline after infection with $A$. hydrophila.

\section{Supplementary Files}

This is a list of supplementary files associated with this preprint. Click to download.

- Table7.pdf 